Litinfinite Journal

ISSN: 2582-0400 [Online]

CODEN: LITIBR

Vol-2, Issue-1 ( $2^{\text {nd }}$ July, 2020)

Page No: $17-21$

DOI: 10.47365/litinfinite.2.1.2020.17-21

Section: Article

\title{
Decanonizing Cultural Myths: A Reading of Sanjukta Dasgupta's Lakshmi Unbound: A Soliloquy
}

\author{
Sayan Parial ${ }^{1}$ \\ Postgraduate student, University of Gour Banga \\ Malda, West Bengl, India \\ Mail I.d.: sayan.ganguly97@gmail.com
}

\author{
Samipendra Banerjee ${ }^{2}$ \\ Assistant Professor \\ Department of English \\ University of Gour Banga \\ Malda, West Bengal, India \\ Mail I.d.: samipendra@yahoo.com
}

\begin{abstract}
Myths have always been used as coercive apparatuses to reinforce order and to naturalize gender stereotypes in the phallocentric discourse eliminating and subsiding women's voice as "other". Many feminist critics seek to dismantle those institutionalized practices through revising, reimagining and reinterpreting mythological interpretations This paper portrays the deconstructive strain in Sanjukta Dasgupta's poem "Lakshmi Unbound: A Soliloquy" unmasking the institutionalization of the pure image of a household lady by patriarchal methodolatry and critiques the attribution of meaning through mythical representation by mainstream culture to impose a passive role upon women restricting in the domestic space. This paper also brings to light the commodification of women's body as a space for control, discipline by the male gaze by treating as a secondary figure to the primacy of the male and demythologizes the myth of the angel in the house.
\end{abstract}

Keywords: Deconstruction, Demythologization, Commodification, Institutionalization, Space

Myths are the carriers of cultural codes of human civilization since the very beginning. Myths have always been used as a device to attribute certain meanings to cultural practices and traditions to perpetuate order and domination in a patriarchal society. In the discourse of patriarchy, mythical interpretations always confine women's role through muting women-voice and fabricating a binarization between superior/inferior, original/other, etc. Anti-feminist vein can easily be traced in literary practices where legitimization of certain stereotypes regarding gender inequality is indoctrinated through constant repetition of the stereotypes. Many feminist critics seek to demythologize those institutionalized practices through revising, reimagining and reinterpreting mythological interpretations. As Adrienne Rich comments "Re-vision-the act of looking back, of seeing with fresh eyes, of entering an old text from a new critical direction-is for us more than a chapter in cultural history: it is an act of survival" (Rich, 18). Demythologization is a postmodernist approach which is used by the feminist critics to deconstruct the myths of womanhood to challenge the traditional notion 
of femininity. Myths have always been used as a weapon to make women as agents of patriarchy to transmit conventional ideas about the ideal image of women from generation to generation. With the advent of Derrida's "Deconstruction," a sudden shift occurred in the dynamics of different disciplines of thought including feminism. Postmodern feminism under the impression of the concept of deconstruction encapsulates demythologization or decanonization of cultural myths to unmask the ideological constructs in mainstream culture. Decanonization in Feminist criticism is the process of destabilizing the deterministic patriarchal norms. Canon is regarded as manufactured legitimacy in accordance with ideologies, political interest, hierarchism to marginalize or exclude the interest and accomplishment of minorities. Feminist critics question the canon formation and seek to decanonize power relations. Language is a medium through which myths are canonized. In the discourse of power politics, language is used as a vehicle for the naturalization of women suppression through androcentric implications of certain myths in different works of art. The hegemonic structure is infused in cultural myths by making women as ideological targets to perpetuate gender stereotypes. Women have always been portrayed as passive characters by separating them from the male public domain and confining them within the domestic space. Feminist critics question the phallocentric authority against the deliberate implementation of the process of othering and reestablish the women subjectivity through the celebration of the expression of the muted in the realm of wilderness.

Sanjukta Dasgupta's "Lakshmi Unbound: A Soliloquy" interrogates the androcentric cultural myth which idealizes the image of a housewife through imposing gender stereotypes and reconstructs the role of women beyond the barriers of domestic space. Intertextual elements in this poem critique the male-centric notion of women as a serving machine to provide love, nurturance. The poem starts with two epigraphs. The first one is a quotation from Virginia Woolf, a prominent feminist critic of the twentieth century, where she destabilizes the myth of "angel in the house": "Killing the Angel in the House was part of the occupation of a woman writer". Myths are signifiers that signify our existence. The myth of angel is an apparatus to subside women's role in a patriarchal worldview. Sanjukta Dasgupta brings this to demystify the image of Lakhsmi, a housewife within the four walls, and to deconstruct the forceful imposition of "pure" image which limits women's individuation. The poet wants to kill the angel that inhabits within Lakhsmi as it is the only way to "to fly kites", "to climb trees", "to read and write", "to sing and dance", "to climb mountains", "to swim in the seas", "to do what" she likes, "Whenever" she likes, etc. The angel in the house who is ideal, submissive, subservient, passive should be replaced with the mad woman in the attic which is horrible, disruptive, powerful, and anti-institutional. The poet here implies the domestic space as a place of silence for women, which appropriates psychological coercion. In the second epigraph the poet brings an extract from Rabindranath Tagore's poem Mukti (translated as Freedom): "With downcast eyes and veiled head I have spent twenty-two years in your house /That's why both at home and without/ Everyone says I am Lakshmi, Sati /An extremely good woman!' In this extract, we see a complete submission of women's subjectivity in front of patriarchal authority. Feminists critics argue that women body have always been held as a commodity or a space for control, discipline by the male gaze and always been treated as a "secondary figure to the primacy of the male" (Nayar, 100) and always been naturalized as an irrational, mysterious by the male discourse and always been marginalized by ghettoizing 
Litinfinite Journal

ISSN: 2582-0400 [Online]

CODEN: LITIBR

Vol-2, Issue-1 ( $2^{\text {nd }}$ July, 2020)

Page No: $17-21$

DOI: 10.47365/litinfinite.2.1.2020.17-21

Section: Article

women-agency. Lucy Irigaray's work Speculum of the Other Woman (translated 1985), and This Sex Which Is Not One (1987) propose that the woman always lacks a subjectivity in Western discourses because she is constructed always as the "other" of the man, never as a free subject with her own identity. The female is always nothing more than a deviation from the norm which is the male. As Irigaray puts it, in the 'logic of sameness' there is 'man' and 'not-man', A and not-A (or A-minus). This means that instead of two separate autonomous entities A and B, we have one positive (A) and it's negative. The second term/identity is only what the first is not. All difference between the sexes is eradicated through this "logic"' (Nayar, 102). In this poem, a crisis of identity is visible. This crisis reminds us of Anne Sexton's poem "Housewife":

"Some women marry houses.

It's another kind of skin; it has a heart, a mouth, a liver and bowel movements.

The walls are permanent and pink.

See how she sits on her knees all day, faithfully washing herself down.

Men enter by force, drawn back like Jonah into their fleshy mothers.

A woman is her mother.

That's the main thing" (Sexton, Allpoetry ${ }^{1}$ ).

It shows the limiting role-playing of a housewife in domestic space by sacrificing her agency. The repressed psyche of that woman is constantly being raped by the domineering male authority in the discourse of family. Beauvoir comments that othering of women is done through by putting a veil of mystery around woman-space and by edifying a mythopoeic space for perpetuating a binary between rational male and emotional women. Beauvoir stressed on women's otherness. Postmodern feminists take this stance of Beauvoir and advocates in favour of this otherness as a space of possibilities as it can be seen as a privileged space outside the male-dominated world. Postmodernist feminists critique the essentialist stance world and the male rationality or logos in the discourse of patriarchy. In the 1990s Ludwig Klages coined the term "logocentrism". It put emphasis on logic or reason. The logocentric discourse always tries to validate binarization and to eradicate binarization she has to be "Alakhsmi" as she "can't ever be Lakshmi". In Lakshmi Unbound: A Soliloquy the narrator outbursts her repressed desires saying: "I want to be mad/I want to be bad/I can't be in corners of four walled spaces/I can't be in eddies/I want to flow in the mainstream/I want to be in whirlpools/I want to roam and run"

The narrator here seeing a wild zone to escape from the identity constructed in the context of the patriarchal family. Redefinition of wholeness can be achieved in disorder, wilderness. Breaking silence can be devised as a resistance to the hegemonic discourse. The narrator wants to "dream" being free from linguistic suppression, psychological repression, and

\footnotetext{
${ }^{1}$ Sexton, A. (n.d.). Housewife by Anne Sexton - Famous poems, famous poets. - All Poetry. Retrieved from https://allpoetry.com/Housewife
} 
physical oppression. Showalter talks in her "cultural model" about a no-man's land to celebrate the expression of suppressed nostalgia free from "patriarchal methodolatry". Dream space of woman-psyche is the place where the liberating act can be done through resistance and the reinvestigation of mythical interpretations, as it can be said: "to become a resisting rather than an assenting reader and, by this refusal to assent, to begin the process of exorcizing the male mind that has been implanted in us"(Blanchard, 66). The narrator expresses: "I can't be Lakshmi/I will ever fail this endurance test /I have to speak /I have to cry /I have to scream/I have to laugh".

Woman-agency can only decipher the hegemonic ideologies beneath the socially constructed myths by questioning the power politics inherent in the matrix of patriarchy. When the narrator expresses her desire to sing "the freedom song", it reminds us VNS Matrix's slogan: "We are the modern cunt/positive anti reason/unbounded unleashed unforgiving"("VNS Matrix"). The "jewels" which represent beauty idealized by the male gaze has to be overthrown by the "gypsy spirit" which is the real "wealth". This "gypsy spirit" is the spark of freedom, a fire which can inflame the women's agency and can unbind Lakhsmi as the title suggests itself. The title reminds us of Shelley's poem "Prometheus Unbound". Prometheus' revolt against god is the revolt against authority which feminists vote for. Lakhsmi's desire to challenge the phallocentric authoritarian dynamics to deconstruct the ideal fabric of women's sphere and to reconstruct a space of freedom beyond the boundaries of order can be symbolically related to the challenge of Prometheus against God, the masculine entity. If we deconstruct the word "Alakhsmi" we will come across a pejorative implication in the mythological interpretation. Alakhsmi can be compared with Rig Vedic goddess Nirrti, goddess of the realm of sorrow. In Nirrti there is the absence of "rta" means order and the presence of disorder, lawlessness, the disorder, or the wilderness that feminists seek. It also recalls in our mind the portrait of Kali, goddess of destruction. In Lina Gupta's "Kali, the Savior" (Gupta, 113), Kali is presented as an iconoclastic figure to decentre gender hierarchies in cultural myths. According to her "Kali as a woman, as a wife, knows what her status should be. As she dances the dance of de-struction she communicates her responses to the way things are and the way they should be. That is, in her destructive dance she creates her reality (Dalmiya, 129).

The last line "Trap me if you can!" decanonizes male discourse which determines women's role. The desire of Killing the "angel" and reinstalling the "madwoman" in the female psyche is the urge that is sought by the narrator to break the confining space reinforced by the maledominant discourse in the cultural dynamics.

\section{Works Cited}

i. $\quad$ "10 Poems by Anne Sexton, Confessional Poet | LiteraryLadiesGuide." Literary Ladies Guide. N.p., n.d. Web. 6 Aug. 2020. Web. 10 June 2020. < https://www.literaryladiesguide.com/classic-women-authors-poetry/10-poems-by-annesexton/>

ii. $\quad$ Blanchard, Lydia. "Women And Fiction: Literature As Politics". Studies in the Novel. 12. 1(1980). pp.65-72. JSTOR. Web. 10 June 2020. < https://www.jstor.org/stable/i29532015> 
Litinfinite Journal

ISSN: 2582-0400 [Online]

CODEN: LITIBR

Vol-2, Issue-1 ( $2^{\text {nd }}$ July, 2020)

Page No: $17-21$

DOI: 10.47365/litinfinite.2.1.2020.17-21

Section: Article

iii. Dalmiya, Vrinda. "Loving Paradoxes: A Feminist Reclamation of the Goddess

Kali." Hypatia 15.1 (2000): 125-150. Print.

iv. DasGupta, Sanjukta. Lakshmi Unbound. Chitrangi, 2017. Print.

v. Gupta, Lina. Kali the Savior. In After Patriarchy: Feminist transformations of world religions,ed. Paula M. Cooey, William R. Eakin, and Jay B. McDaniel. Maryknoll, New York: Orbis Books. 1991. Print.

vi. Irigaray, Lucy. Speculum of the Other Woman. Trans. Gillian Gill. New York: Cornell UP, 1987. Print.

vii. Irigaray, Lucy. This Sex Which Is Not One. Trans. Catherine Porter. New York: Cornell UP, 1985. Print.

viii. Nayar, Pramod K. Contemporary Literary and Cultural Theory: From Structuralism to Ecocriticism. Noida: Pearson. 2010. Print.

ix. Rashley, Lisa Hammond. "Revisioning Gender: Inventing Women In Ursula K. Le Guin's Nonfiction." Biography, vol. 30, no. 1, 2007, pp. 22-47. JSTOR, <www.jstor.org/stable/23540596. Accessed 6 Aug. 2020.>

x. $\quad$ Rich, Adrienne. "“When We Dead Awaken: Writing as Re-Vision" (1971)." Available Means (n.d.): 268-282. Print. 